\title{
Notes on the vocalizations of North Island Saddleback (Philesturnus rufusater) and South Island Saddleback (Philesturnus carunculatus)
}

Peter Boesman

In the following we briefly analyze and compare voice of North Island Saddleback (Philesturnus rufusater) and South Island Saddleback (Philesturnus carunculatus). We also try to quantify the extent of any vocal differences using the criteria proposed by Tobias et al. (2010), as a support for taxonomic review. We have made use of sound recordings available on-line from Xeno Canto $(\mathrm{XC})$.

There are only a few recordings available for South Island Saddleback, but these nevertheless illustrate quite well its vocabulary:

A nasal chatter song:

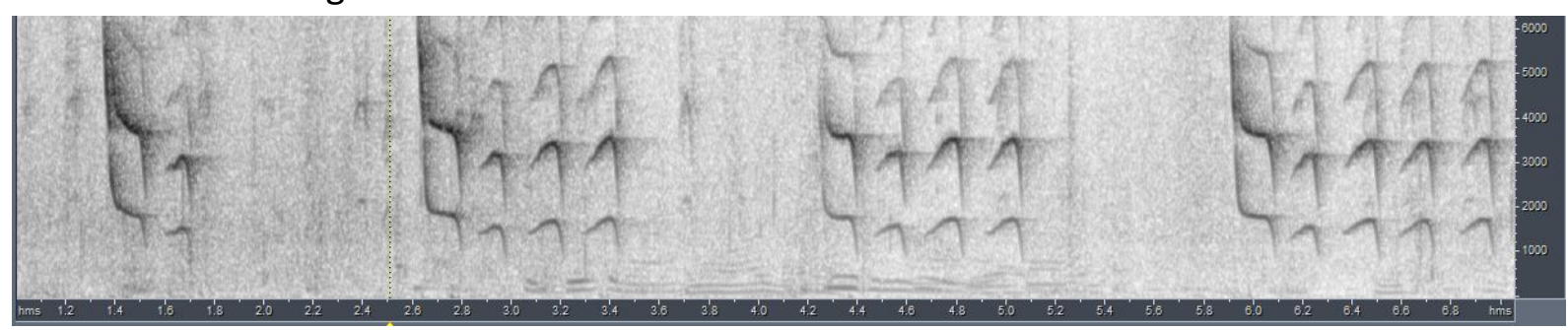

A double note song "pee-chew...pee-chew..":

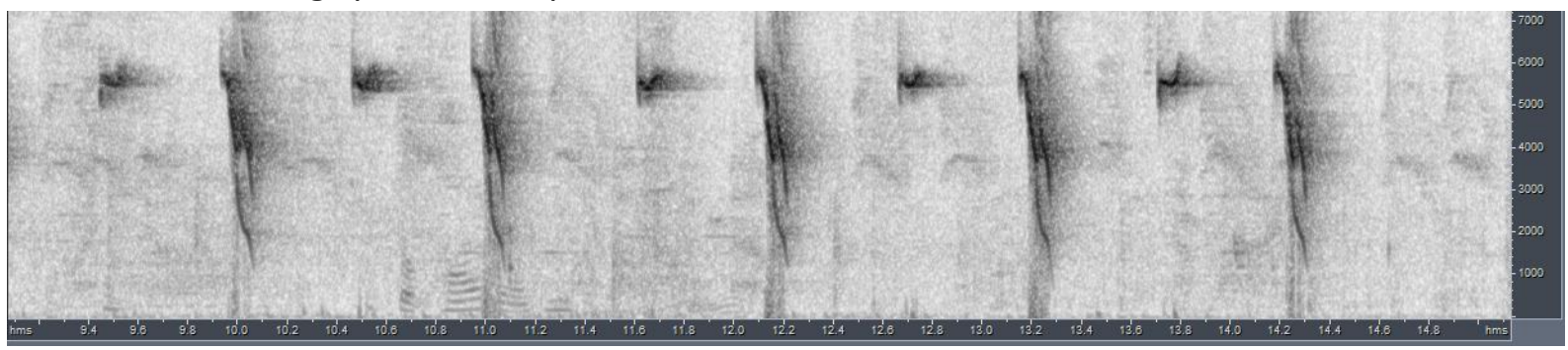

A soft trilled series, probably contact calls:

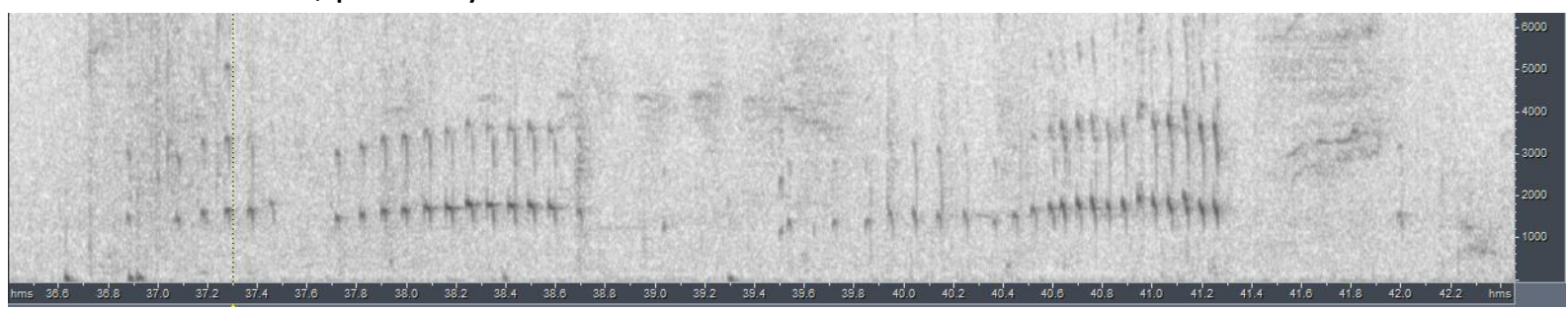

High-pitched notes and variations

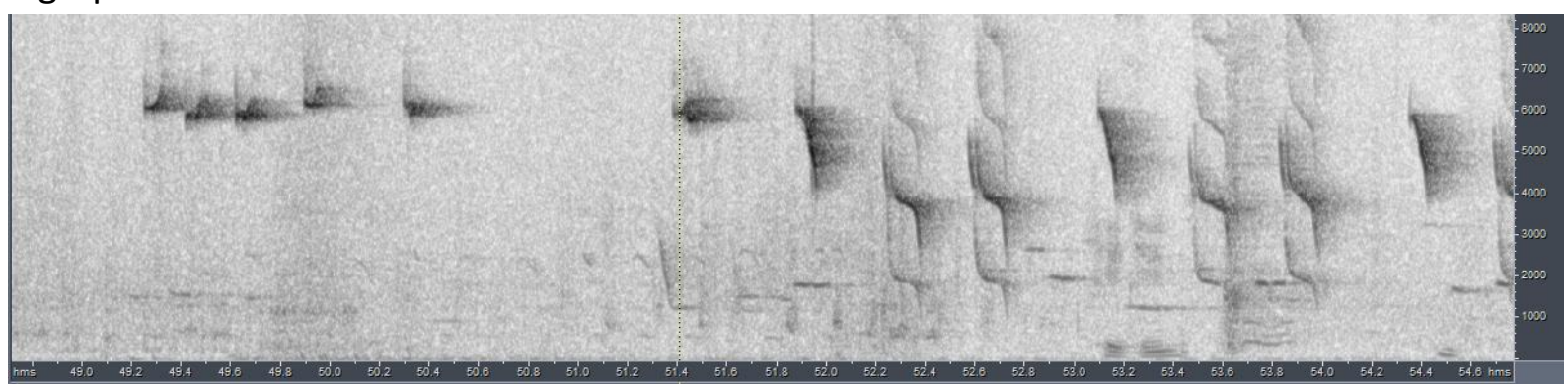




\section{HANDBOOK OF THE \\ BIRDS PF/THE WORLD}

\section{ORNITHOLOGICAL NOTES}

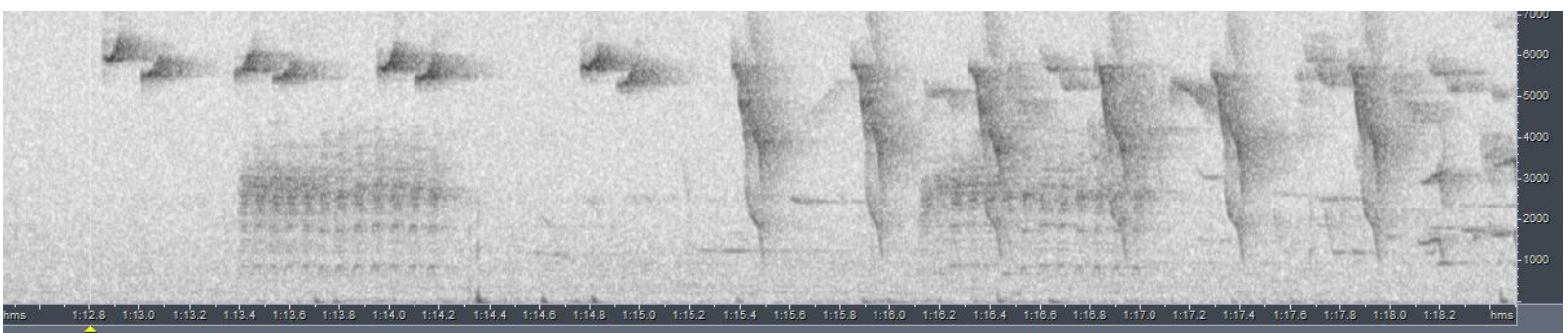

There are more recordings available for North Island Saddleback, for which I have tried to find best matches with the above vocalizations of South Island Saddleback:

A nasal chatter song: clearly the homologous vocalization but all differ quite some from carunculatus (much faster repetition of shorter notes):

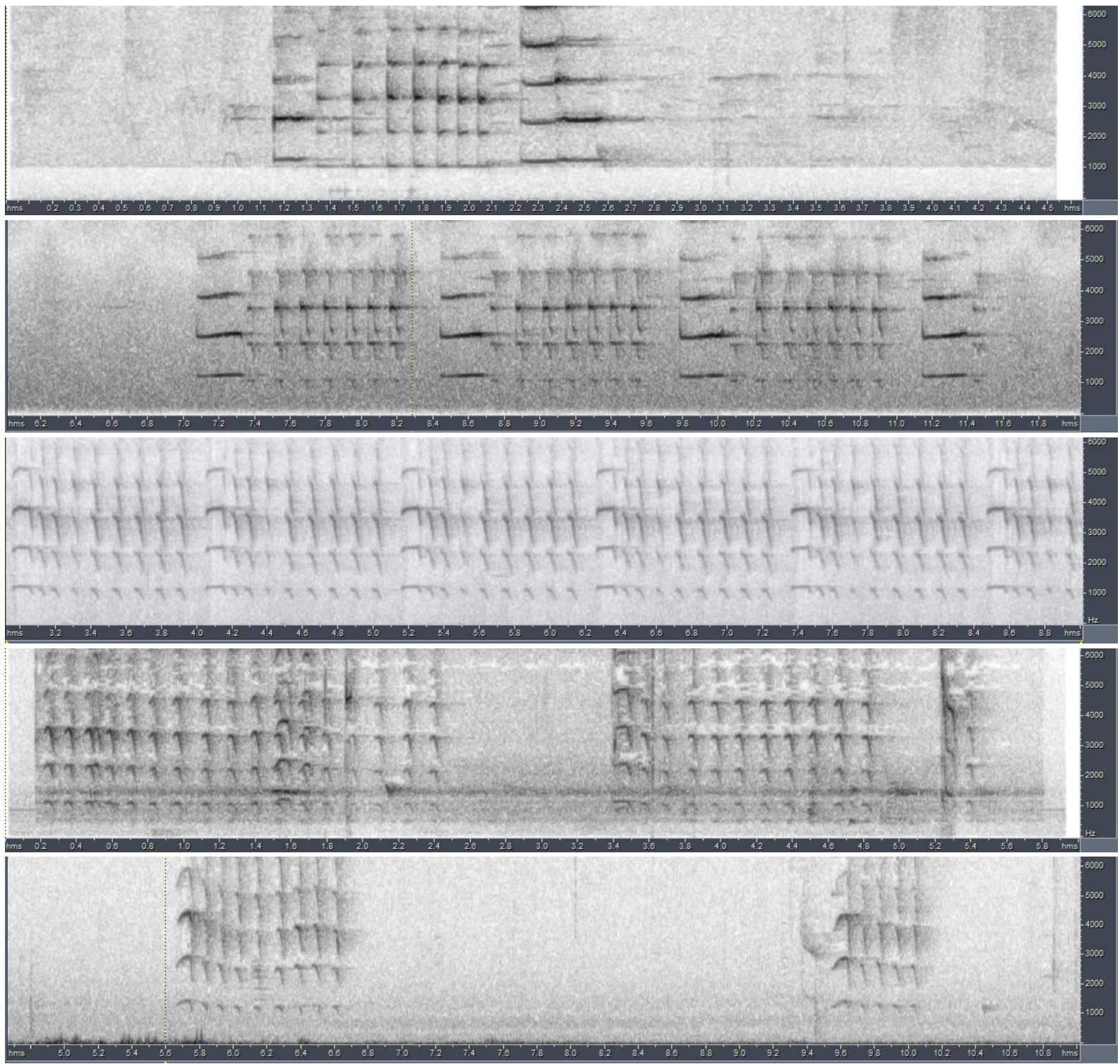




\section{HANDBOOK OF THE \\ BIRDSPITHE WORLD}

\section{ORNITHOLOGICAL NOTES}

except for the following one which comes closest to carunculatus (but still sounding quite different):

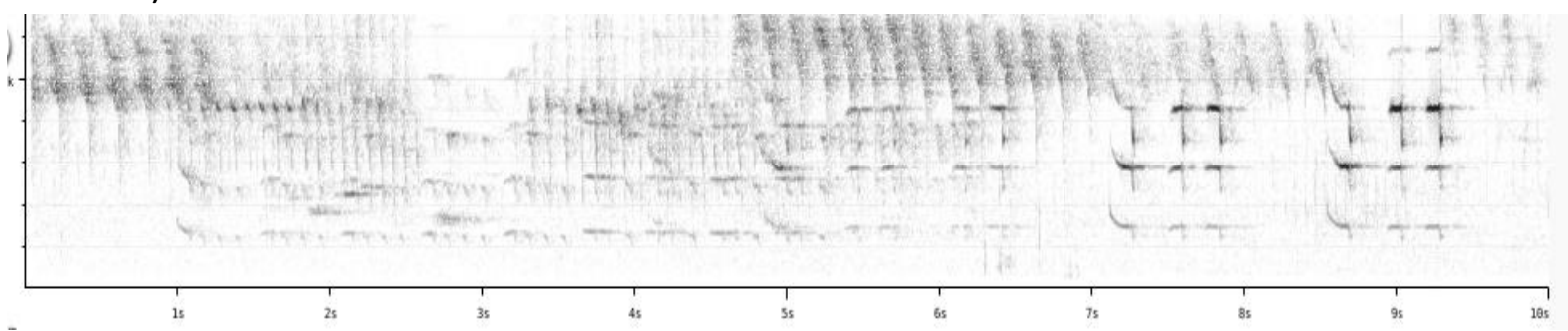

A double note song "pee-chew...pee-chew.." of carunculatus: nothing really similar could be found for rufusater, only quite different fairly high-pitched "cheek" notes:
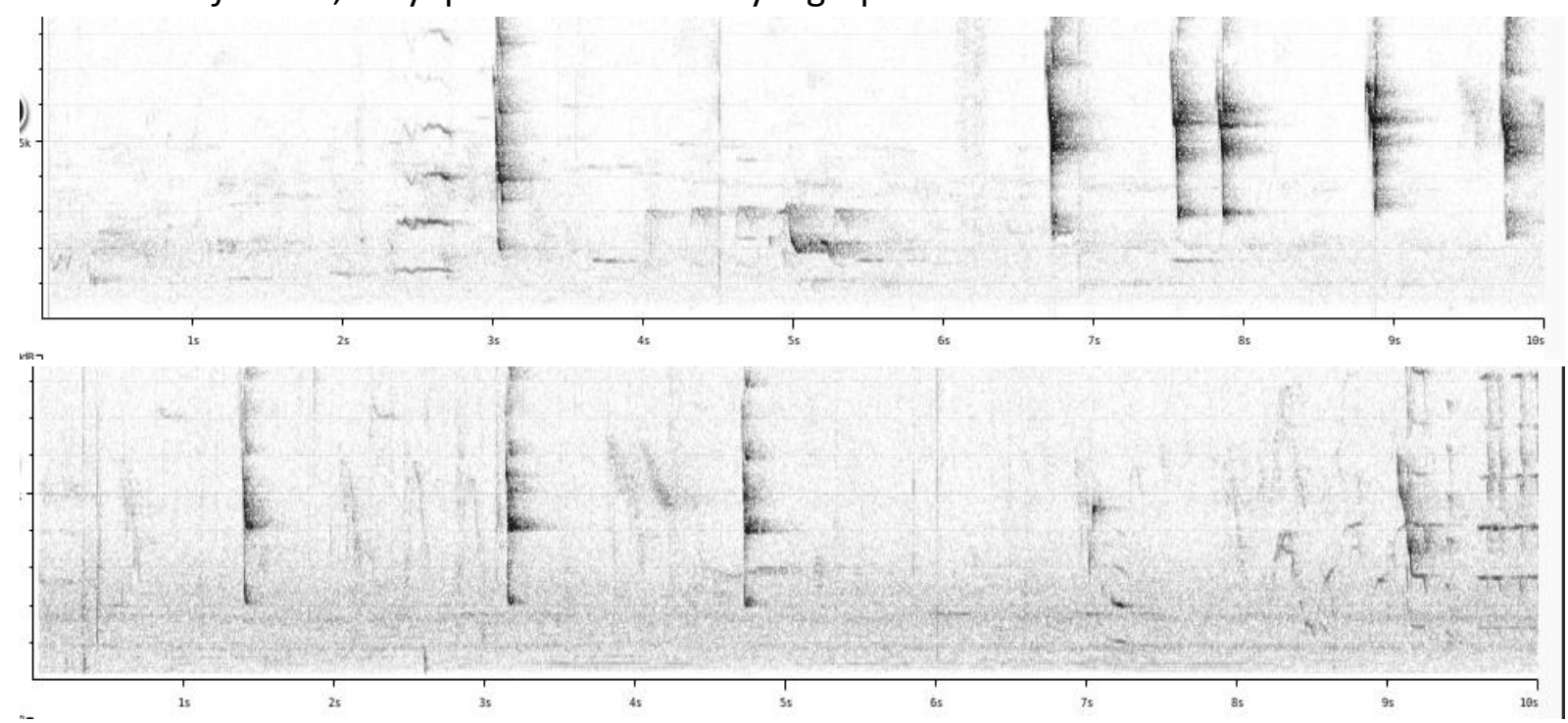

And other vocalizations:

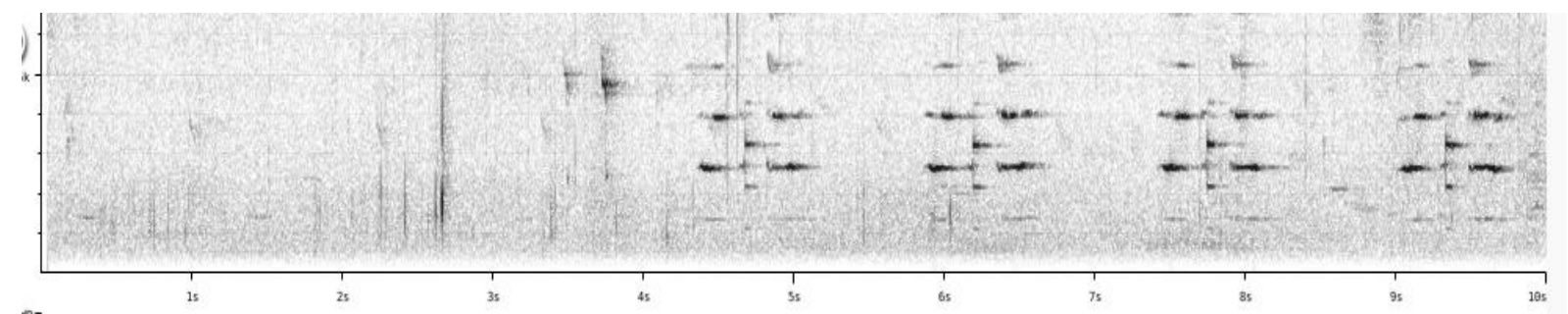

As stated earlier, there are only few recordings available, especially of carunculatus, but from the above it would seem that there is likely a considerable vocal difference.

Vocabulary is extensive, as can be deducted from the four pages (!) in HANZAB (2006) on voice, but these focus on North Island Saddleback, and resemblance with South Island Saddleback is only briefly touched.

More recently, an extensive study on voice of South Island Saddleback was performed (Ludwig \& Jamieson 2007), confirming e.g. again the much slower chatter song. 

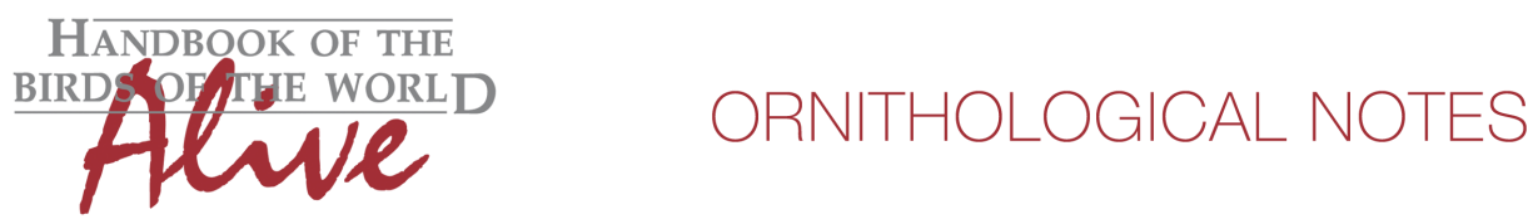

All in all, given that the chatter song is reportedly the most common vocalization, there seems to be a distinct difference in pace (3) and note shape (1), for which a total vocal score of 4 could be given when applying Tobias criteria.

This note was finalized on 30th January 2016, using sound recordings available on-line at that moment. We would like to thank in particular the sound recordists who placed their recordings for this species on XC: Patrik Åberg, Chris Bennesh, Dan Lane, Johnny Rommens, Nick Talbot and George Wagner.

\section{References}

Higgins, P.J., Peter, J.M. \& Cowling, S.J. eds. (2006). Handbook of Australian, New Zealand and Antarctic Birds. Vol. 7, Part A. Boatbill to larks. Oxford University Press, Melbourne, Victoria.

Ludwig, K., Jamieson, I.G. (2007). Phrase types, repertoire size and repertoire overlap in the South Island saddleback (Philesturnus carunculatus carunculatus). Notornis 54: 201-213.

Tobias, J.A., Seddon, N., Spottiswoode, C.N., Pilgrim, J.D., Fishpool, L.D.C. \& Collar, N.J. (2010). Quantitative criteria for species delimitation. Ibis 152(4): 724-746.

\section{Recommended citation}

Boesman, P. (2016). Notes on the vocalizations of North Island Saddleback (Philesturnus rufusater) and South Island Saddleback (Philesturnus carunculatus). HBW Alive Ornithological Note 213. In: Handbook of the Birds of the World Alive. Lynx Edicions, Barcelona. (retrieved from http://www.hbw.com/node/932171 on 6 September 2016). 